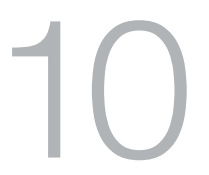

\title{
Multi-level Housing Policy in Australia
}

\author{
Patrick Troy
}

\section{Introduction}

Since settlement in 1788, housing policy in Australia has always been subjected to several levels of regulation and control exercised by different levels of authority. For a broader discussion of multi-level governance (MLG) of urban development see Stilwell and Troy (2000).

Initially, regulations governing housing were introduced by the central colonial administration in London, although early governors had a high degree of discretion over urban regulations, including control over aspects of housing. Later, a degree of devolution of responsibility for aspects of housing occurred as the realities of centralised administration overwhelmed the central administration in each colony. The vehicle chosen for the devolution of responsibility varied between the colonies. For example, the Police Land Act 1833 in the NSW colony was used to enforce compliance with building safety and health regulations in NSW until 1837 with the promulgation of the Building Act (Troy 1988). 


\section{Housing policy responsibilities and issues before federation}

Local government was created in NSW (Larcombe 1961) as the creature of colonial, later state, administration and was given responsibility for administering central policy and building regulations - especially over housing. Local government was created in the other colonies at different stages in their development and with different responsibilities. There was, however, a wide disparity between and within the colonies in relation to the development of accommodation standards and their enforcement. By and large, the colonial administrations were happy to 'live and let live' as long as there was no 'disaster' resulting in injury or loss of life. The quality of accommodation was essentially determined by the strength of demand and regulations governing housing were enforced in an almost 'accidental' way.

As local governments matured and their urban centres grew, the larger of them sought more engagement in aspects of housing policy beyond the structural, health and fire safety regulations introduced by the respective colonial administrations.

The larger urban centres sought to take more enlightened approaches to the quality of urban spaces and the dwellings in them, frequently initiating campaigns for the improvement of various aspects of the accommodation in their areas. These initiatives did not always win the approval of colonial administrations. At times, colonial administrations had larger ambitions than the local authorities, and vice versa. But at all times, the underlying issue was more a reflection of differing ambitions about the extent to which local communities - many of which were forced to accept responsibility to establish local government to provide local services - could decide what they wanted, how much and the standards that should apply to developments in their area.

Local communities could make a case for 'local exceptionalism', arguing that they knew what they wanted and were unhappy about being required to comply, initially with colonial, later state, policies and standards. Enforcement of colony-wide policies and associated regulations over local ambitions could become the avenue of political expression and opposition to the central administration. Central administrations were often accused of being 'out of touch'. 


\section{The early years of federation}

The advent of statehood that came with federation in 1901 did not increase the powers of local governments and left undisturbed the wide range of responsibilities and standards relating to the construction and operation of dwellings that were formerly held by the colonial administrations. In the delineation of responsibilities between the states and the Commonwealth, there were significant differences between the states of the new nation in relation to many aspects of housing, and the Commonwealth had virtually no authority in the area.

Throughout the early years of the Commonwealth, each state pursued housing policies with little regard to what others were doing.

These differences had little effect for much of the early period of federation. The range of climatic conditions, the differences in economic development and the locally available building materials, together with the differing scale and nature of urbanisation, meant that the states were under little pressure to pursue standardisation of building regulations or to explore issues of equitable access to accommodation. This inevitably meant that there were significant differences between them in the reach and detail of housing regulation. Commencing in 1910, Queensland led the states in addressing the affordability of housing for low-income households by introducing a Workers Dwelling Scheme under which low-income households could have an advance to build a home on a site they owned.

Other states followed suit with variations that included, in South Australia from 1910, being able to buy a house and land through the State Bank of South Australia. Western Australia chose in 1912 to establish a Housing Board with the power to build a house on land already owned by an applicant. In 1912 in NSW, a local authority, the Sydney Corporation, was empowered to build dwellings for rent. Victoria in 1914 extended the involvement of local government in housing by giving it the power to borrow to buy land and build dwellings for leasing. The Victorian scheme failed because ratepayers were reluctant to support ventures into municipal housing. 


\section{Intergovernment relationships and responsibility sharing}

In short, although housing issues had long engaged colonial and state governments as well as their local government authorities, the history of the relationship between the two levels of government was not propitious. The power of colonial administrations and, later, the state governments, meant that they could establish regulations relating to the structural and fire safety aspects of housing and ensure that elemental aspects of health, especially for ventilation and sanitation, were taken into account in building new housing. Once reticulated water services were developed, states also defined the conditions applying to their provision. The further development of water-based sanitation systems was followed by articulation of regulations governing their provision. Local authorities, however, had the responsibility of administering the policies. State administrations had limited abilities to enforce compliance. In many areas, local authorities simply 'ran dead' on issues of quality, not only because they believed housing standards were too high but also because they had limited resources to address them. State and local administrations basically ignored issues of access to accommodation and paid little attention what might be termed the equity aspects of housing provision.

As evidence emerged of the inadequate slum housing in which large proportions of the population lived in the older, inner areas of the major settlements, the limited abilities of local authorities to ameliorate them became more obvious.

The Commonwealth had no interest or experience in administration of such matters, although it was to have responsibilities in such matters once it began the process in 1912 of building the nation's capital, Canberra, in what was essentially a 'greenfield site' (note that the Commonwealth retained responsibility for control of development of Canberra until 1988 when the Australian Capital Territory was given a large degree of administrative independence). As the Commonwealth slowly evolved and grew in confidence, it acquired the obligation for the accommodation of its officers. This meant that it had to ensure that they enjoyed housing of comparable quality irrespective of the location in which they served. In accepting this obligation, the Commonwealth began the process of developing standards and regulations, which meant that it often adopted the standards of the 'leading states'. 


\section{Housing issues in the inter-war years}

Following World War I, the Commonwealth, in 1919, enacted the War Service Homes Act to provide houses for sale to ex-servicemen. The houses were expected to comply with the relevant state regulations so their construction did not entail competition between levels of government over housing standards.

Apart from accepting, in 1928, its responsibility for housing of the residents of the new national capital, Commonwealth initiatives were restricted, in the same year, to permitting the Commonwealth Savings Bank to advance funds to state authorities and the private sector to increase the funds available for home purchase. The scheme was directed at middle-income households and founded on the notion that the housing would comply with state regulations. Little housing was financed under the scheme. A proposal by conservative Prime Minister Joseph Lyons in the 1934 election to introduce a national housing scheme under which low-cost housing would be provided in association with state and local government and include a slum clearance program was aborted following the election by Robert Menzies as attorney-general (later to become prime minister), who argued that the Commonwealth did not have the constitutional power to do so.

\section{Increasing social concerns}

Deterioration of the state housing situation continued during the 1930s Depression and was accompanied by rising concern among social activist groups over the health and social consequences of the slum conditions under which significant proportions of the population lived. The regulatory framework devised by state governments and administered by local authorities seemed impotent in responding to the situation.

By the 1940s, there was increasing concern over the housing experience of large proportions of the population. Rents were high and, although home ownership had nationally reached 50 per cent by 1911, the level of home ownership in the major cities was significantly lower (Troy 2012). There was an unacceptable level of homelessness and overcrowding was common, in spite of state and local regulations drawn up to reduce the challenges to health that overcrowding brought. Reviews of housing 
conditions undertaken by various state agencies and religious and political reformist groups revealed the parlous conditions under which many lowincome households lived.

\section{The growing case for national intervention in housing policy}

Early in World War II, concern was expressed about the social welfare of the lower income members of society, leading to the creation in 1941 by the conservative government in the Commonwealth parliament of a Joint Parliamentary Review of Social Security that revealed the crisis in social welfare and, in particular, the conditions under which a large minority of the community was housed. This was the first national review of housing undertaken by a national government in Australia. Following a recommendation of the Joint Parliamentary Review of Social Security and a change to a Labor government, the Commonwealth created the Commonwealth Housing Commission, which was charged with the obligation to:

inquire into and report [on] matters in relation to the public safety and defence of the Commonwealth: the present housing position in Australia; and the housing requirements of Australia during the post-war period (CHC 1944).

Each state had a shortage of accommodation due to the low level of building activity in the 1920s and 1930s that was exacerbated by wartime limitations on domestic construction. There was, in addition, rising concern in the larger cities, especially Sydney and Melbourne, over the slum housing conditions under which low-income households lived. Menzies, however, used the opportunity in his May 1942 speech, 'The Forgotten People' - while claiming that there was no class war - to set out in considerable detail his view of the middle class, which he saw as the national backbone. He argued that the middle class had a 'stake in the country', the material aspect of which he averred found concrete expression in the habits of frugality and saving:

for a home of our own ... one of the best instincts in us is that induces us to have one little piece of earth with a house and a garden which is ours: to which we can withdraw, in which we can be among friends, into which no stranger may come against our will. 
He also took the view that the wealthy could look out for themselves and that those 'at the other end of the scale was the mass of unskilled people who were almost invariably well organized and with their wages and conditions safeguarded by popular law' (Menzies 1943). Like the 1928 initiative, he saw the opportunity for the Commonwealth to improve the housing conditions of the middle class by increasing opportunities for them to acquire their own home.

In making its report to the Commonwealth, the $\mathrm{CHC}$ took a larger view than that adumbrated by Menzies in asserting: 'We consider that a dwelling of good standard and equipment is not only the need but the right of every citizen' (CHC 1944, emphasis in original).

The CHC made a number of recommendations commenting on housing design, estate development, the need for better planning and on the development of a housing program under which households would not be required to pay more than 20 per cent of household income on rent.

\section{Outcomes of Commonwealth-state negotiations}

The 'National picture' that emerged from negotiations over the proposed Commonwealth-state Housing Agreements (CSHA) revealed widely divergent views about the need for, and nature of, a housing program. In response to the CHC's proposal that advances be made to the states to enable them to acquire land for urban development and to construct housing on the condition that the states each establish town planning processes and schemes, the states adopted different positions. At the 1944 meeting of premiers to discuss the details of the Commonwealth's proposal for the creation of a research-based planning system, the states resisted. The most assertive was Queensland whose premier, Frank Cooper (Labor), announced his opposition to the proposal saying:

while the exigencies of the war demanded sacrifices of Queensland so that Australia might be served, after the war Queensland would consider her claims as paramount. ${ }^{1}$

The premier of Victoria, Albert Dunstan (Country Party), who had earlier agreed on the need for a scientific basis for town planning, declined to participate, saying his government had already submitted its own legislation to parliament and there was no need to go over the same ground.

1 From the record of 1944 meetings between Commonwealth and states (AA A9816/4 1943/1423 Part 1). 
The Commonwealth had also proposed that, initially, housing built under a Commonwealth-funded program would be for rental, with exservicemen being given preference until the shortage of housing was addressed. Here states also revealed their opposition, with Queensland and Tasmania saying that those given access to housing had to be able to acquire it. The two states displayed little preparedness to depart from strongly held ideological views about the approach to be adopted in relation to the creation and ownership of housing. This was paradoxical because both were Labor states directly challenging and refusing to participate in a scheme that the national Labor Government proposed. This was mildly embarrassing because a conservative government in South Australia, which had mounted an imaginative, large scale and successful public rental housing scheme since 1936, refused to 'sign up' for fear that they might have to compromise on what it held was a superior scheme. It was able to use its state bank to facilitate home purchase and ensure that the site planning and development of estates was of a high order, enjoying a high reputation as a consequence. South Australia took the view that its housing program was superior to that proposed by the Commonwealth and did not 'sign up' to the CSHA until 1956.

In the postwar period, the states also agreed to continue the uniform income-taxation provisions they had agreed to fund the war effort. This initiative profoundly affected the distribution of power between the Commonwealth and states, significantly increasing the power of the former and reducing that of the latter. The central control, especially over the raising of loans to fund infrastructure investment, materially affected the capacity of the states to provide the water services and transport infrastructure needed to foster and direct housing development to accommodate burgeoning population pressures resulting from Commonwealth migration programs.

\section{The Commonwealth-state Housing Agreements}

The CSHAs under which funds were advanced to each state for the construction of housing (initially for rent) ran for an agreed but extendable period initially of five years.

The first agreement ran from 1946 to 1956 . There was considerable philosophical disagreement over the role of the state in housing, with some reluctance on the part of Commonwealth ministers and officials to pursue the program. The program was developed by a federal Labor 
administration on the assumption that it was for 'public housing'. Although the sale of such housing was not excluded, it was assumed that, until the housing crisis was 'solved', housing built under the agreement should be for rent. Two states, Queensland and Tasmania, both Labor states, argued strongly that housing should be able to be sold to sitting tenants and refused to 'sign up'.

The Commonwealth undertook to share the burden of any losses incurred under the program but insisted that economic rents should be struck to recoup outgoings on dwellings and that rents should not exceed 20 per cent of income.

Some elements within the Commonwealth administration opposed the idea of a public housing program, arguing that it was outside the Commonwealth's powers, and also out of a belief that government ought not be involved in such matters. How much such views influenced the Commonwealth approach to negotiations with states it is impossible to say. Suffice it to note that the Commonwealth Treasury took a restricted view of the purposes to which Commonwealth funds for a housing program could be applied. The 'triumph' of the Commonwealth's limited views on such matters is the proximate reason why the great majority of Commonwealth-funded housing projects were developed with almost no community facilities, thus making them less attractive as places in which to live and which ultimately helped foster the stigmatisation of households who lived in them.

\section{The postwar period}

Housing, although a basic need, elicits a wide range of responses. The Commonwealth clearly responded to the objective conditions that existed in the mid-1940s by constructing a program to alleviate them. There was an obvious ideological dimension to the initiative. In the view of the major proponents of the public housing program, the 'market system' had failed and the solution was to try to create an alternative set of rights in relation to housing.

The Commonwealth's engagement in housing always had a degree of ideological tension to it that affected the way in which CSHAs were negotiated and administered. Sometimes the tension was between the Commonwealth and various states; on other occasions, the tensions were within the Commonwealth or within one or more states. 


\section{The sale of public housing}

Although the Commonwealth's involvement in housing was not high on Menzies' agenda, once he regained office as prime minister in 1949 he did not move to change the direction of the public housing program until 1954 when, during an election campaign, he announced that housing built by the states under the CSHA could be sold to sitting tenants. The initiative, reflected in the CSHA negotiated in 1956 when the Commonwealth allowed public housing to be sold on concessional terms using funds granted to permanent building societies, effectively undermined the intention and development of the public housing program. The initiative was entirely consistent with Menzies' 'Forgotten People' speech (Menzies 1943) and began the process of destruction of the CSHA.

\section{Home ownership}

The public housing program under the CSHA was successful and popular but, in pursuit of the objective of increasing home ownership and withdrawing from housing provision through the states, several Commonwealth ministers sought to limit the program and all sought ways of influencing development decisions. Part of their response in 1964 was to make home ownership more attractive by developing a Home Savings Grant Scheme under which households that saved through an approved lending institution for a specified period could be awarded a grant to be used to increase their deposit on a dwelling. At the same time, Minister Leslie Bury sought to dramatically restructure the Commonwealth's approach to housing and was appointed the first minister for housing. Bury sought to increase direct Commonwealth control over housing programs and, like his predecessor, William Spooner, minister for national development, was concerned that too much of the kudos associated with housing resided with the states.

It is important to recall that the level of 'owner building' - that is, houses built by individuals for themselves - exceeded the level of housing built under the CSHA or by registered builders, significantly increasing the level of owner occupation (Troy 2012) and, in an important sense, was a strong measure of the instinct to which Menzies (1943) had referred. The level of owner building was entirely a response within the states, although Commonwealth control over the supply of building materials indirectly affected the rate of completion of houses. 


\section{Commonwealth politics and policy responses to slum housing}

Slum housing had attracted the attention of social reformers and its existence was a major reason that the federal government became involved in improving the housing stock. During the first 20 years of the CSHAs, the Commonwealth did not see slum clearance as the most important housing initiative so did not pursue the issue with great energy. Senator Annabelle Rankin, who replaced Bury in 1966 as housing minister, was determined to eliminate slum housing and to develop a research base to housing policy articulation and program development. She argued for a slum-clearance program, with the resulting vacant inner-city land being made available for higher income housing on the grounds that it was too valuable to be used to accommodate low-income households. In this she was at odds with Spooner, who had argued that low-income households should be accommodated at high density in inner-city areas that traditionally voted Labor. In proposing such a policy, Spooner was suggesting concentrating low-income households in inner electorates and, in so doing, ensuring that Labor voters would not become a 'problem' in suburban areas that returned conservative representatives. More conservative ministers proposed that the Commonwealth should not be engaged in housing programs for low-income earners at all but, nonetheless, argued that it should have more direct control over how the housing program was developed and administered.

Although the Commonwealth formally eschewed direct responsibility for the details of housing developments, several ministers sought to encourage slum-clearance projects in inner areas out of a belief that, by committing themselves to such (expensive) projects, the states would have fewer resources available for construction of traditional houses in the suburbs that were perceived to be a threat to conservative electorates. The series of slum-clearance projects that were undertaken in Melbourne and Sydney were important recognition of the need to be seen to be eliminating substandard accommodation. The fact that the replacement housing was built in such a way that it was difficult to sell separately was to some extent a defensive response of the states to ensure that they retained control over a stock of housing for low-income households. 


\section{Late 20th-century reforms}

The Labor administration from December 1972 to December 1975 gave confused signals over its approach to housing issues. It wanted to maintain a public housing program delivered through the states but also wanted to make it easier for low-income households to purchase their houses. The CSHA of 1973 increased the targeting of low-income households.

\section{Commonwealth provision of housing}

Legal advice tendered to the Commonwealth in the early 1970s indicated that it had the power directly to provide housing to the majority of the population for whom it provided social benefits (pensions, child welfare etc.) or employed (including in the armed services) by extending its activities to include other citizens. This advice provided the justification for the Commonwealth to undertake a major housing project in inner Sydney (the Glebe Estate) under which housing was acquired, renovated and new housing built to provide a significant increase in public housing in the area.

In 1975, it also created the Australian Housing Corporation to enable it to directly deliver housing. In its creation the Commonwealth was trying to build on its powers to deliver housing to ex-servicemen. The change of government at the end of 1975 led to the abolition of the Australian Housing Corporation before it had developed any programs in the states. The Commonwealth, in 1976, reintroduced the Home Savings Grant Scheme that had been phased out in 1972 .

\section{From public to welfare housing}

Following a review of the CSHA, the Commonwealth Government under Malcolm Fraser decided in 1978 to change the basis of the agreement with the states to three years by changing the focus of program from a public housing program to a welfare-housing program under which the states were to provide matching funds. To further sharpen the focus, the Commonwealth stipulated that the basis of rents was to be changed from 'economic rents' to market rents (reduced in negotiations to 'marketrelated rents'). The ambition to charge market rents rather than economic rents was to reduce the Commonwealth obligation to underwrite the program by reducing the demand for public housing. 
The changes to the administration of the CSHA in 1978 completed the change of the original housing ambition from a public housing program to a welfare program and, once the introduction of the policy of marketrelated rents took effect, to a residual social-housing program. The final stage of conversion to a residual social-housing program was accompanied by the demonisation/stigmatisation of residents in such housing estates as they became concentrations of households of multiple disadvantage - the consequences of the Commonwealth's strictures on what could be funded under the CSHA meant that the lack of facilities and poor access to employment accentuated the social disadvantage such households experienced.

To reduce the burden on the Commonwealth and the level of public housing, the Commonwealth also decided in 1979 to increase the proportion of funds devoted to welfare housing by increasing the funding for pensioner housing and for housing Indigenous Australian communities. The Commonwealth was positioning itself to vacate the field. The 1978 CSHA was due to run out in mid-1981. A strong group of Liberal ministers wanted to terminate the agreement but the minister, Tom McVeigh, a traditional Country Party man from Queensland, supported continuation of the agreement and succeeded in getting the Commonwealth to agree to another three years. ${ }^{2}$ Although he was impressed by the project, he was less successful in preventing the sale of the Glebe Estate to the NSW Government in 1981. The Commonwealth also directly boosted home ownership in 1982 by reintroducing taxation deductions for mortgages for home owners, radically changing the controls over trading banks' lending limits and relaxing the regulations under which savings banks operated, and introducing a mortgage- and rent-relief scheme.

\section{The segmentation of welfare housing and Commonwealth independent action}

The Commonwealth again changed tack on housing with the election of a Labor Government under Bob Hawke in 1983. The new CSHA that was negotiated in 1984 extended the segmentation of welfare housing to

2 Tom McVeigh, personal communication, 2013. 
additional identified groups within the community. The Commonwealth also removed further controls over both trading and savings banks, setting in train the massive increases in house prices that followed.

The Commonwealth's decisions in the 1980s accorded preferential treatment of capital gains on housing. In particular, its decision not to tax capital gains on the 'family home' and to permit negative gearing on investment by home owners in additional dwellings introduced distortions in the housing market that affected the ability of states to secure planned developments.

The non-taxation of capital gains in their houses encouraged home owners to 'over invest' in their dwelling, leading to the development of 'McMansions' in the expectation that, when they retired, they would be able to sell their homes and 'downsize', leaving them with a significant capital sum they could use to fund their retirement. The negative gearing of second dwellings enabled high-income households to claim the 'loss' incurred in raising a mortgage on its purchase as an offset on their income tax. This was highly inequitable in its effects.

\section{1st-century issues and reforms}

The 'experiment' with public housing through the CSHA came to an end as the Commonwealth increased the focus on housing as part of the social security system and further segmented the provision of housing to specific groups. The proportion of the stock of housing held as public housing fell to 4 per cent by the national census of 2006. Home ownership, which had been the emphasis of Commonwealth policy, had reached 70 per cent by 1966 and has slowly declined since. The last CSHA was signed in 2003 and, in 2009, was replaced by the National Australian Housing Assistance plan.

\section{Discussion of the MLG Australian housing policy system}

The history of responses of state and Commonwealth governments to the housing crisis in 1945 was one of contestation between the two levels of government. In the early period, the Commonwealth acted as though it was unsure of its constitutional authority in housing. Its confidence 
grew with its increasing command over national economic policy. States were limited by a lack of financial resources from providing infrastructure. The massive increase in urban populations, stimulated largely by Commonwealth immigration programs and by the migration of rural dwellers to the city as rationalisation/modernisation of primary production proceeded, created increasing demands for urban housing. The growing demand for housing was accompanied by the population's rising expectations of housing quality and home ownership. The massive surge in owner building, together with the ability from 1956 to buy houses built under the CSHA, lifted owner occupancy rates.

Commonwealth governments, especially of the more conservative cast, were concerned that the kudos from housing programs funded under the CSHAs fell largely to the states. Commonwealth officers and political leaders sought increasing direct control over what housing was built where. States were required to provide detailed proposals of their programs. The Commonwealth was asserting power over the states in areas that it had formerly claimed to have no responsibility.

Throughout the life of the Commonwealth initiative to create a public housing system in which households could exercise a choice to buy their own home or elect to rent accommodation in well-planned and well-located housing, the problems of MLG were starkly revealed. The difficulties that emerged in trying to establish continuities and consistency within and between the Commonwealth and state administrations proved to be insuperable. The time taken to design and construct housing and to establish communities was long but could be subverted by lack of consistency or continuity in policy development. States could enter into programs designed to secure long-run housing programs to produce efficient and equitable urban development with confidence, only to find that the Commonwealth adopted policies driven by a contrasting ideological agenda with little or no consultation with them and that undermined their activities.

\section{Shared public and private responsibility over housing}

One of the paradoxes that exists in Australia is that there is now a significant disjunction between the approaches by Commonwealth and state governments over who bears the responsibility for areas of social policy such as housing. Households may experience difficulties in securing adequate housing of an acceptable standard but be unsure as to which 
level of government might be able to resolve those difficulties. The level of government with the greatest capacity to provide them with the level of ontological security they desire is undoubtedly the Commonwealth. The Commonwealth's power over income tax and its ability to construct favourable financial conditions enables it to make promises to help households secure home ownership that inevitably comes closest to their ambitions. State governments have never had access to comparable levels of resources.

Local government rarely had resources sufficient to embark on housing programs. Although they notionally had the power to affect the quality, scale and type of housing provided in their area, local governments were increasingly made to understand that they were creatures of state governments as they were required to adhere to state-determined housing targets. The independence of local government promised by state governments was limited by state decisions seemingly more responsive to pressure from developer interests to reduce the influence of local governments over development control plans.

The promise of the programs constructed under the CSHA was founded on notions of stability and on equitable treatment between states and between different groups within them. While for a moment it seemed that there was sufficient shared experience to warrant a 'national' response to the accommodation needs of the population, it soon unravelled. The ambitions of Queensland and Tasmania, who wanted residents of housing built under a public scheme to be able to buy it, and the decision by South Australia to stay out of the Commonwealth scheme are evidence of the fragility of the idea of national purpose.

The propensity of Commonwealth ministers (and their departments) to directly shape the contours of housing policy compounded the difficulties that multi-level government administration of housing programs confronted. Much of this contestation came from the fundamentally different ideological origins of the definition of the boundaries within which housing programs were developed and delivered. The initial Commonwealth proposals were developed out of a notion of the welfare state that evolved out of the experiences of the Depression enriched by radical views about social justice. Some states (and, indeed, at the Commonwealth level) held to a more robust view that reliance on 'the market' would produce an acceptable, (and in this view) desirable, outcome. 
There was always a tension between Commonwealth and state agencies that advised on housing programs. The state agencies were staffed by people who had direct experience of developing housing and of administering it and were consequently immediately aware of the human dimensions of the policies and programs. The Commonwealth agencies had few staff with direct experience. These differences could be observed in meetings between Commonwealth and state ministers and officers. The state housing agencies were often led by officers with long experience in delivering housing and who were committed to the ideals of public housing. The Commonwealth was staffed by few officers with direct experience and their careers were not necessarily bound up in quite the same way with the program's success.

The initial CSHAs were developed out of a shared understanding between the Commonwealth and the states over the accommodation needs of the population. There was always a determination that, as far as possible, those needs would be equitably met. The differences between Commonwealth and state administrations and their ideological preferences, however, meant that MLG issues were magnified at each level by inconsistency of commitment due to internal tensions, such as differences between them in the approach to home ownership. Conservative Commonwealth governments tended to emphasise home ownership. Labor governments acknowledged the attractions of home ownership but were more concerned over the need to secure equitable treatment for all groups in society. The distribution of rights in housing was seen as a strong indicator of the balance in society.

When only one-third of households were owner-occupiers, two-thirds were sensitive about the quality of their housing and their security and could respond to Commonwealth initiatives to acknowledge their concerns. By the time two-thirds of households were owner-occupiers or were given significant advantages in investment in housing and the Commonwealth had successfully 'split' the 'welfare' lobbyists by ensuring religious and charity activists had resources to provide accommodation, housing had receded as a national concern and was transformed into a concern over the private financing of the debt incurred in home ownership. The lifting of controls over banks requiring them to hold a certain proportion of their investment portfolios in housing and to limit the level of housing mortgages to a set maximum proportion of household income was followed by a rapid inflation in house prices. The developer industry and associated financial interests, including the major banks, which enjoyed 
Commonwealth government 'protection', were increasingly influential in controlling decisions affecting the scale and nature of development, including the level and nature of infrastructure provision, further reducing the ability of local governments to protect or promote the nature of developments.

Although states agreed to establish planning authorities to provide urban development plans and strategies as a condition of obtaining Commonwealth funds under the CSHA schemes, they took no initiatives to prevent rent-seeking by existing land owners. Consequently, state and local governments had little influence over the price, amount or nature of accommodation. The nature of the housing industry changed, with largescale land and housing developers being able to exert pressure on state and local governments to influence the types of dwellings permitted and the nature and mix of infrastructure to support them.

The Commonwealth-state model of delivery of housing that was built on notions of acknowledging differences between the states, especially in relation to the lower income members of society, failed. The last agreement in 2003 was final evidence of the consequences of trying to address their needs without broad consensus and continuity of commitment. The dominance of the push for home ownership that was achieved by the Commonwealth delivering significant subsidies to achieve that ownership, which was undertaken with little consultation with the states, ensured that state governments were always at a political disadvantage in exploring/ responding to housing challenges. The failure was also, no doubt, due to the increasing influence of the centralising approach adopted by Council of Australian Governments (COAG).

The conservative reaches of the Commonwealth succeeded in reducing its commitment to public housing. It had swept up a range of programs designed to address the accommodation needs of specific groups by recasting them as state responsibilities. There was no common commitment among the states to a public housing program. The 'agreements' between the states and Commonwealth provided for states to arrive at their own programs. National housing objectives were broadly defined in the new National Affordable Housing Agreement (COAG 2009). The agreement was innovative because it directly acknowledged the role of local government in the provision of housing, albeit in its role to endorse and apply state regulations in relation to building approval processes and local planning and development approval. That is, it 
accorded local government little direct involvement in housing policy but provided the excuse that housing costs were high because of local approval processes and administrative and operational charges that were vaguely described as 'charges that influence housing affordability'. It was also innovative because it set out a description of the responsibilities of the Commonwealth and the states and territories in achieving a number of outcomes. The rhetoric of the agreement was acceptable but provided no level of resources on which the states could rely to develop or manage programs to produce the desired outcomes.

\section{Addressing MLG challenges of the future in housing policy}

The new landscape of housing policy was recognised in the way in which housing was dealt with under the developing COAG. Created in 1992, COAG was designed to achieve national standards in delivery of services, including housing, and to give more confidence to state administration in the development of their programs. It was also designed to reduce pressure on Commonwealth administration.

The housing 'crisis' that was manifested in the 1990s and early 2000s was revealed in increasing concern over affordability of housing. The Commonwealth's policies in relation to housing finance, including its preferment of investment in rental housing, created speculation in rental housing and its reduction of funding for state housing programs led to the 'crisis'. Although the crisis was real, Commonwealth reluctance to embark on an ameliorative program was consistent with its view that housing issues were essentially the responsibility of the states. The influence of neo-liberalist philosophy, which saw the outcomes as a 'natural' part of the playing out of the market, also led to a Commonwealth response designed only to deal with the consequences of extreme market outcomes that were socially unacceptable. Although the Commonwealth held to a view that it had vestigial responsibility for some welfare housing issues, its basic position was that, in providing the control of the major elements of the economy, it was doing all that was necessary to provide for Commonwealth involvement in the governance of housing. This was reflected in the fact that to the extent that the Commonwealth accepted some responsibility 
for housing, it was administered through the Department of Social Security from 1996-98 and the Department of Families and Community Services after 1998.

Milligan and Pinnegar (2010) provide a useful exploration of the origins of the 2009 Commonwealth housing initiative, including identification of the limits of the National Affordable Housing Agreement program, pointing out that it does not address 'the absence of a long term investment plan sufficient to enable social housing to grow and to be reconfigured to better match current and projected needs' (338).

The sorry history of Commonwealth engagement in housing policy and programs is outlined by Milligan and Tiernan (2011). The history focuses on direct program delivery but eschews exploration of the effects of the suite of initiatives directed at taxation, preferential financing or cash grants for owner-occupiers and the 1978 introduction of market-related rents for public housing, all of which have profoundly affected the shape and nature of the supply and demand for housing. Save for the 1978 changes to the rents to be paid for public housing under the CSHA, few of these initiatives were the administrative responsibility of housing portfolios but were designed and delivered through central 'economic' agencies.

State housing authorities have never been high in the administrative ranking in the states. By and large they have been, and are, agencies charged with responsibility to deliver real accommodation services to real people. Over the last 60 years, the greater part of the resources available to them for housing came from the Commonwealth, so they were never dependent to a high degree on the vagaries of state budgets. The changing climate and framework within which they operate under COAG, whilst being described as an agreement reached between state and Commonwealth governments to deliver greater flexibility, now places the states in a more precarious position on housing issues. The assurances that prevail so long as the states annually make progress on Commonwealthset performance indicators simply presage contestation between the two levels of government.

The risk is that, rather than reducing the levels of conflict, the multi-level governance of housing now in place will invite the Commonwealth to be more interventionist but, in doing so, it will be less focused on delivery of accommodation than on attempting to structure the financing of housing. 
Taking the long view suggests that the housing crisis experienced up to the end of World War II was due directly to the failure of the market to deliver socially acceptable outcomes. There was no national approach to, or consideration of, housing issues; consequently, the fragmentation of responses from each state could not be expected to produce an even outcome. For a while after World War II there was an agreed view that there should be a national approach to housing. The states had some responsibilities to deliver appropriate amounts and quality of housing. Local governments had little say in the quality or quantity of housing produced. For the last 50 years, as its control over the economy has increased, the Commonwealth has inexorably retreated from direct influence over the quality or quantity of housing. It has been content to use its powers over interest rates and monetary policy to influence supply. To some degree, it has tempered its commitment to the efficacy of 'the market' by making contributions to the accommodation needs of selected minorities, such as its support for the 'welfare' housing provided by churches and other groups that work for 'good causes', such as aged citizens and housing for Aboriginal communities, but eschewed opportunities to see housing as a right of citizens.

\section{References}

CHC (1944). Final Report, 25 August 1944 Ministry of Post-War Reconstruction, Commonwealth Housing Commission, Sydney.

COAG (2009). National Affordable Housing Agreement: Intergovernmental Agreement on Federal Financial Relations, www.federalfinancialrelations. gov.au/content/npa/national_agreements/national-housing-agree ment.pdf [Accessed: 21/12/2014].

Larcombe, F. (1961). The Development of Local Government in New South Wales. Cheshire, Melbourne.

Menzies, R.G. (1943). The Forgotten People and Other Studies in Democracy. Angus and Robertson, Sydney.

Milligan, V. \& Pinnegar, S. (2010). The Comeback of National Housing Policy in Australia: First reflections. International Journal of Housing Policy, 10(3): 325-44. doi.org/10.1080/14616718.2010.506747 
Milligan, V. \& Tiernan, A. (2011). No Home for Housing: the situation of the Commonwealth's housing policy advisory function. Australian Journal of Public Administration, 70(4): 391-407. doi.org/10.1111/ j.1467-8500.2011.00746.x

Stilwell, F. \& Troy, P. (2000). Multilevel Governance and Urban Development in Australia. Urban Studies, 37: 909. doi.org/ 10.1080/00420980050011154

Troy, P. (1988). Government Housing Policy in New South Wales 1788-1900. Housing Studies, 3(1): 20-30. doi.org/10.1080/ 02673038808720611

- (2012). Accommodating Australians: Commonwealth Government Involvement in Housing. Federation Press, Sydney. 
This text is taken from Multi-level Governance: Conceptual challenges and case studies from Australia, edited by Katherine A. Daniell and Adrian Kay, published 2017 by ANU Press, The Australian National University, Canberra, Australia.

dx.doi.org/10.22459/MG.11.2017.10 